\title{
Cerebrospinal fluid analysis in the context of CNS demyelinating diseases
}

\author{
Análise do liquido cefalorraquiano no contexto das doenças desmielinizantes do SNC \\ Sandro Luiz de Andrade Matas 1,2, Felipe von Glehn'1,3, Gustavo Bruniera Peres Fernandes', \\ Carlos Augusto Senne Soares ${ }^{1}$
}

\begin{abstract}
The central nervous system demyelinating diseases are a group of disorders with different etiologies, characterized by inflammatory lesions that are associated with loss of myelin and eventually axonal damage. In this group the most studied ones are multiple sclerosis (MS), neuromyelitis optic (NMO) and acute disseminated encephalomyelitis (ADEM). The cerebrospinal fluid is essential to differentiate between these different syndromes and to define multiple sclerosis, helping to assess the probability of Clinical Isolated Syndrome turn into multiple sclerosis.
\end{abstract}

Keywords: multiple sclerosis, acute disseminated encephalomyelitis, neuromyelitis optic, cerebrospinal fluid, clinical isolated syndrome, demyelinating.

\section{RESUMO}

As doenças desmielinizantes do sistema nervoso central são um grupo de desordens de diferentes etiologias, caracterizadas por lesões inflamatórias associadas a perda da mielina e eventualmente dano axonal. Neste grupo de doenças, as mais estudadas são a esclerose múltipla (EM), a neuromielite óptica e a encefalomielite aguda disseminada. 0 estudo de liquido cefalorraquiano é essencial para o diagnóstico diferencial entre as diferentes síndromes e para a definição de EM, ajudando a estimar a probabilidade da transformação da síndrome clínica isolada em EM.

Palavras-Chave: esclerose múltipla, encefalomielite aguda disseminada, neuromielite óptica, líquido cefalorraquiano, síndrome clínica isolada, desmielinizante.

The central nervous system(CNS) demyelinating diseases are a group of disorders with different etiologies, sometimes unknown, characterized by inflammatory lesions that are associated with loss of myelin and eventually axonal dama$\mathrm{ge}^{1}$. In this group, because of the higher frequency, the most studied ones are multiple sclerosis (MS), neuromyelitis optic (NMO) and acute disseminated encephalomyelitis (ADEM), therefore, we will describe bellow the main cerebrospinal fluid (CSF) findings of each of these disorders.

\section{Multiple sclerosis}

Multiple sclerosis (MS) is a disease that affects 2.5 million people in the world and about 400.000 in the United States $^{2}$. MS is a primary disease of the central nervous system (CNS), clinically characterized by relapses mediated by acute inflammatory lesions in the white matter, followed by a progressive phase, mediated by axonal and neuronal loss ${ }^{3,4}$. The pathogenesis of MS is mainly driven by central nervous system-invading encephalitogenic CD4 T lymphocytes of both the Th1 and Th17 types. These effector cells can be downregulated by regulatory $\mathrm{T}$ lymphocytes ${ }^{5}$. Current findings indicate that humoral immunity also plays a major role in disease pathogenesis, even though it is not fully understood ${ }^{6}$.

Intrathecal immunoglobulin synthesis in an oligoclonal pattern is the most common immunologic abnormality detected in MS patients ${ }^{6,7}$. These antibodies are produced against many different antigens, indicating localized B-cell expansion in brain, although a definitive association of these cerebrospinal fluid (CSF) antibodies with a consistent antigen has not been established ${ }^{7}$.Oligoclonal bands (OCB) patterns differ between patients but remain constant during disease course ${ }^{8,9}$.

The frequency of CSF OCB differs between study populations. In Europe and in the USA, studies demonstrated more than $90 \%$ of frequency differing from the approximately $60 \%$ frequency in Asian studies ${ }^{1,10}$. In Brazil, a work involving 103 
MS patients demonstrated CSF OCB in $81 \%$ of the cases, not as high as northern studies. It was supposed that immigration miscegenation have influenced the results ${ }^{11}$. Different treatments have not modified CSF OCB IgG pattern, such as immunomodulators, immunossupressors, rituximab and even complete immune ablation, such as in autologous hematopoietic bone marrow transplantation in severe cases of $\mathrm{MS}^{12,13,14}$.However, it was recently demonstrated that natalizumab treatment can promote CSF OCB disappearance in some cases ${ }^{15}$.

CSF OCB IgG is not specific for MS and could be also detected in some neuroinfectious and autoimmune diseases (e.g. neurosyphilis, Lyme disease, subacute sclerosingpanencephalitis, ADEM), but because of the mentioned high frequency, its presence in association with the patient's clinical presentation and neuroimaging data could confirm MS diagnosis, according to McDonald criteria ${ }^{4,16}$. Furthermore, in the case of clinical isolated syndrome (CIS), the first relapse of a CNS demyelinating disease, the presence of CSF OCB can predict the conversion to clinical definite multiple sclerosis $(\mathrm{CDMS})^{17}$. After a 3 years follow up of 192 patients with CIS, Bosca and colleagues showed that $60 \%$ of them evolved to CDMS. Ninety four per cent of these patients presented CSF $\mathrm{OCB}$ at the time of the first relapse, meaning that the association of CIS and their presence could increase to 9 times the risk of CDMS conversion. Masjuan and colleagues ${ }^{18}$ demonstrated that CSF OCB had 91.4\% sensitivity and 94.1\% specificity in CIS conversion to MS, which was superior to the prediction associated to abnormal brain $\mathrm{MRI}^{19}$.

The CSF examination may show evidence of inflammatory activity during relapses as slight elevation of mononuclear white blood cells (pleocytosis) with cell counts varying between 5 to 50 cells/ mm3 in one third of MS cases. Cell count above 50 is unusual and indicates that other diagnosis should be excluded. Also, slight elevation of protein levels varying between 45 to $70 \mathrm{mg} / \mathrm{dl}$, with increased globulin to album ratio can be found in $40 \%$ of the cases ${ }^{10,20}$.

Intrathecal immunoglobulin synthesis could be assessed qualitatively (OCB detection) and quantitatively (Immunoglobulin index). The identification of IgG-specific oligoclonal bands is performed with IgG-isoelectric focusing on agarose gel followed by immunoblotting. The patterns were interpreted qualitatively by comparing the presence or absence of OCB in CSF and serum. There are 5 patterns, described as follow: Pattern 1=no OCBs in CSF or serum; pattern 2=CSFrestricted OCBs; pattern $3=\mathrm{CSF}-$ restricted OCBs and additional identical bands in CSF and serum (combination of patterns 2 and 4); pattern 4=identical OCBs in CSF and serum; pattern $5=$ monoclonal bands in CSF and serum. Only patterns 2 and 3 indicate intrathecal IgG synthesis?

CSF and serum concentrations for immunoglobulins and albumin are measured by nephelometry and analyzed within the same analytical series. The others immunoglobulins (IgA,
IgM) could also be studied in the same way. The CNS does not produce albumin or immunoglobulin $\mathrm{G}$ (IgG) and their CSF level in normal conditions correspond to $0.5 \%$ and $0.25 \%$ from the serum, respectively. Therefore, CSF/serum albumin quotient, QAlb=Alb CSF [mg/l]/Alb Serum [g/l], is used to assess the blood-brain barrier (BBB) function. As the upper reference limit of QAlb is age dependent, Qlim(Alb) was calculated as $4+(X / 15)$, with $X$ representing the patient's age, according to Reiber's study ${ }^{21}$. Dysfunction of the blood-CSF barrier was defined as QAlb > Qlim(Alb).With this information, Tourtellote ${ }^{22}$ developed quantitative expressions of the intrathecal humoral immune response based on calculation of the CSF/serum quotients (QIgG) with QIgG=IgGCSF [mg/l]/IgG Serum [g/l]. The upper limits of the respective reference ranges Qlim(IgG) is calculated against QAlb according to Reiber's revised hyperbolic function ${ }^{22}$. Values for QIgG exceeding Qlim(IgG), in this case IgG index values above 0.7, were considered to indicate intrathecal immunoglobulin synthesis $^{23}$. Reiber and Felgenhauer ${ }^{24}$ developed a diagram, which is divided in 5 specific areas: $1=$ normal value; $2=\mathrm{BBB}$ disturbance without IgG intrathecal production; $3=\mathrm{BBB}$ disturbance with IgG intrathecal production; 4=IgG intrathecal production without BBB disturbance and 5=Insignificant values.

\section{Neuromyelitis optica}

Neuromyelitis optica (NMO) is an inflammatory relapsing disease of the human central nervous system (CNS) of putative autoimmune etiology which is characterized by severe attacks of myelitis and optic neuritis $(\mathrm{ON})^{25}$. In 60-80\% of cases, NMO is associated with antibodies to aquaporin-4 (AQP4ab), the most abundant water channel in the CNS, and its presence is related to a relapsing and often worse disease course $^{26-28}$.

Jarius and coleagues ${ }^{27}$ demonstrated a substantial lack of intrathecal AQP4-Ab synthesis in patients with NMO Spectrum Disorders (NMOSD). AQP4-Ab were detectable in $68 \%$ of CSF samples from AQP4-Ab seropositive patients with NMOSD, but in none of the CSF samples from AQP4$\mathrm{Ab}$ seronegative patients with NMOSD. Therefore, they concluded that testing for CSF AQP4-Ab did not improve the sensitivity and specificity of the current diagnostic criteria for NMO and thus, its CSF measurement is unnecessary for clinical purposes ${ }^{29}$.

CSF-restricted oligoclonal IgG bands, a hallmark of MS, are absent in most NMO patients, with the studies demonstrating around $15-30 \%$ of detection rate ra, $^{90}$. If present, intrathecal IgG (and, more rarely, IgM) synthesis is low, transient, and, importantly, restricted to acute relapses. In addition, QAlb may be elevated both during relapse and during remission, indicating sustained blood CSF barrier dysfunction andsubclinical disease activityin patients with AQP4-Ab positive $\mathrm{NMOSD}^{30}$. 
CSF pleocytosis is present in around $50 \%$ of samples, with cell counts varying between 28 to 57 cells $/ \mathrm{mm}^{3}$, sometimes reaching 2,000 cells $/ \mathrm{mm}^{320,30}$. Frequently, differential cell analysis demonstrates neutrophils, eosinophils, activated lymphocytes, and/or plasma cells. Albumin CSF/serum ratios, total protein and CSF L-lactate levels correlated significantly with disease activity as well as with the length of the spinal cord lesions in patients with acute myelitis ${ }^{30}$. Total CSF protein level is increased between 290 to $640 \mathrm{mg} / \mathrm{dl}$ during relapse and between 33 to $63 \mathrm{mg} / \mathrm{dl}$ at the remission phase. Additionally, CSF findings differed significantly between patients with acute myelitis and patients with acute optic neuritis at the time of $\mathrm{LP}^{20,30}$.

\section{Acute disseminated encephalomyelitis (ADEM)}

Acute disseminated encephalomyelitis is an inflammatory demyelination disease of the CNS, encompassing the white and gray matter of the brain and spinal cord, with a distinct tendency to a perivenous localization of pathological changes ${ }^{31,32}$. Children are mostly affected, with the median age of 6.5 years $^{33}$. Usually, ADEM is monophasic and associated with a temporal and probably also with a causative relationship to infection (e.g. measles, herpes, varicella, mumps, Epstein-Barr or influenza) as well as to preventive vaccination, although the development of vaccines that are based on recombinant proteins, which are not contaminated with undue amounts of myelin antigens, has significantly lowered its related incidence ${ }^{32}$. Typically, the clinical syndrome begins with fever, headache, vomitus and meningeal signs, followed by consciousness and behavioral disturbances, seizures and focal neurological signs. CNS lesions are almost always of similar age, and consist of mostly one distinct pattern: perivenous and sub ependymal inflammation around small vessels in both white and gray matter, with infiltration of lymphocytes, macrophages and to lesser extent neutrophils ${ }^{32}$. The topography of demyelinating lesions has a marked preponderance of the white matter at the corticalsubcortical border. Bilateral deep grey matter lesions (thalamus and basal ganglia) could also be affected ${ }^{34}$. Highly intense infiltrates may also be found in the cerebellum, spinal cord and brainstem.

CSF examination is usually performed to rule out infectious meningoencephalitis and in the majority of cases, shows only minor and unspecific changes. In some cases, it may reveal a mild pleocytosis, with lymphocytes, monocytes and sometimes, plasma cells, usually between 10 to 50 cells $/ \mathrm{mm}^{3}$, no more than $100 / \mathrm{mm}^{3}$. The total protein content is also increased but usually below $100 \mathrm{mg} / \mathrm{dl}^{34}$. CSF OCB may be present only transiently and rarely, with the studies demonstrating a median of $12.5 \%$ of the cases studied ${ }^{32}$. High serum titers of IgG specific for myelin oligodendrocyte glycoprotein (MOG) have been observed in $40 \%$ of the studied cases of $\mathrm{ADEM}^{35}$.

\section{References}

1. Wekerle $H$, Lassmann $H$. The immunology of inflammatory demyelinating disease. In: Confavreux C, Lassmann H, McDonald I, Miller D, Noseworthy J, Smith K, Wekerle H (Eds). McAlpine's Multiple Sclerosis. London, 2006;547-555.

2. Ross A. Strategies for optimal disease management, adherence, and outcomes in multiple sclerosis patients. Neurology 2008;71(Suppl 3): S1-S2.

3. Hauser S L. Multiple lessons for multiple sclerosis. N Engl J Med 2008;359: 1838-1841.

4. Compston A, Coles A. Multiple sclerosis. Lancet 2008;372:1502-1515.

5. Ramagopalan SV, Dobson R, Meier UC, Giovannoni G. Multiple sclerosis: risk factors, prodromes, and potential causal pathways. Lancet Neurol 2010;9:727-739.

6. Antel J, Bar-Or A. Roles of immunoglobulins and B cells in multiple sclerosis: From pathogenesis to treatment. J Neuroimmunol 2006; 180:3-8.

7. Freedman MS, Thompson EJ, Deisenhammer F, et al. Recommended standard of cerebrospinal fluid analysis in the diagnosis of multiple sclerosis. Arch Neurol 2005;62:865-870.

8. Correale J, Molinas MMB. Oligoclonal bands and antibody responses in multiple sclerosis. J Neurol 2002;249:375-389.

9. Bergamaschi R, Tonietti S, Franciotta D, et al. Oligoclonal bands in Devic's neuromyelitis optica and multiple sclerosis: differences in repeated cerebrospinal fluid examinations. MultScler 2004;10: 2-4.

10. Calabresi PA and Cortese I. Inflammatory and demyelinating disorders. In: David N Irani (Ed). Cerebrospinal fluid in clinical practice. Philadelphia, Ed. Saunders Elsevier, 2009:209-223.
11. Senne C, Gomes HR, Puccioni-Sohler M. O exame do líquido cefalorraqueano. In: Tilbery CB (Ed). Esclerose múltipla no Brasil. Aspectos clínicos e terapêuticos. São Paulo, Ed. Atheneu, 2005:117-128.

12. Rudick RA, Cookfair DL, Simonian NA, et al. Cerebrospinal fluid abnormalities in a phase III trial of Avonex (IFNbeta-1a) for relapsing multiple sclerosis. The Multiple Sclerosis Collaborative Research Group. J Neuroimmunol 1999;93:8-14.

13. Saiz A, Carreras E, Berenguer J, et al. MRI and CSF oligoclonal bands after autologous hematopoietic stem cell transplantation in MS. Neurology 2001;56:1084-1089.

14. Piccio L, Naismith RT, Trinkaus K, et al. Changes in B-and T-lymphocyte and chemokine levels with rituximab treatment in multiple sclerosis. Arch Neurol 2010;67:707-714

15. von Glehn F, Farias AS, de Oliveira AC, et al. Disappearance of cerebrospinal fluid oligoclonal bands after natalizumab treatment of multiple sclerosis patients. Mult Scler 2012;18:1038-1041.

16. Polman $\mathrm{CH}$, Reingold SC, Edan G, et al. Diagnostic criteria for multiple sclerosis: 2005 revisions to the 'McDonald Criteria: Ann Neurol 2005;58:840-846.

17. Boscá I, Magraner MJ, Coret F, et al. The risk of relapse after a clinically isolated syndrome is related to the pattern of oligoclonal bands. J Neuroimmunol 2010;226:143-146.

18. Masjuan J, Alvarez-Cermero JC, Garcia-Barragan N, et al. Clinically isolated syndrome, a new oligoclonal band test accurately predicts conversion to MS. Neurology 2006;66:576-579.

19. Tintoré M, Rovira A, Rio J. Do oligoclonal bands add information to MR in first attacks of multiple sclerosis. Neurology 2008;70:1079-1083. 
20. Fredrikson S. Clinical usefulness of cerebrospinal fluid evaluation. Internat MS J 2009;17:24-27.

21. Reiber H. Flow rate of cerebrospinal fluid (CSF)--a concept common to normal blood-CSF barrier function and to dysfunction in neurological diseases. J Neurol Sci 1994;122:189-203.

22. Tourtelotte WW, Shapshak P, Baumhefner RW, Staugaitis SM, Syndulko K. Laboratory aids in the diagnosis of multiple sclerosis (MS). Prog Clin Biol Res 1984;146:313-321.

23. Reiber H. Cerebrospinal fluid--physiology, analysis and interpretation of protein patterns for diagnosis of neurological diseases. Mult Scler 1998;4:99-107.

24. Reiber H, Felgenhauer K. Protein transfer at the blood cerebrospinal fluid barrier and the quantitation of the humoral immune response within the central nervous system. Clin Chim Acta 1987;163:319-328.

25. Wingerchuk DM, Hogancamp WF, O'Brien PC, Weinshenker BG. The clinical course of neuromyelitis optica (Devic's syndrome). Neurology 1999;53:1107-1114

26. Lennon VA, Wingerschuk DM, Kryzer TJ, et al. A serum autoantibody marker of neuromyelitis optica: distinction from multiple sclerosis. Lancet 2004;364:2106-2112.

27. Jarius $\mathrm{S}$, Wildemann B. AQP4 antibodies in neuromyelitis optica: diagnostic and pathogenetic relevance. Nat Rev Neurol 2010;6: 383-392.
28. Akman-Demir G, Tüzün E, Waters P, et al. Prognostic implications of aquaporin- 4 antibody status in neuromyelitis optica patients. J Neurol 2011; 258:464-470.

29. Jarius S, Franciotta D, Paul F, et al. Cerebrospinal fluid antibodies to aquaporin-4 in neuromyelitis optica and related disorders: frequency, origin, and diagnostic relevance. J Neuroinflammation 2010;7:52.

30. Jarius S, Paul F, Franciotta D, Ruprecht K, et al. Cerebrospinal fluid findings in aquaporin-4 antibody positive neuromyelitis optica: results from 211 lumbar punctures. J Neurol Sci 2011;306: 82-90.

31. Murthy JM. Acute disseminated encephalomyelitis. Neurology India 2002;50: 238-243.

32. Menge T, Kieseier BV, Nessler S, et al. Acute disseminated encephalomyelitis: an acute hit against the brain. Curr Opin Neurol 2007;20:247-254.

33. Menge T, Hemmer B, Nessler S, et al. Acute disseminated encephalomyelitis: an update. Arch Neurol 2005;62:1673-1680.

34. Wender M. Acute disseminated encephalomyelitis (ADEM). J Neuroimmunol 2010;231:92-99.

35. Brilot F, Dale RC, Selter RC, et al. Antibodies to native myelin oligodendrocyte glycoprotein in children with inflammatory demyelinating central nervous system disease. Ann Neurol 2009;66: 833-842. 